\title{
Selectivity of commercial, larger mesh and square mesh trawl codends for deep water rose shrimp Parapenaeus longirostris (Lucas, 1846) in the Aegean Sea
}

\author{
HAKAN KAYKAÇ ${ }^{1}$, ADNAN TOKAÇ ${ }^{1}$ and HÜSEYIN ÖZBILGIN ${ }^{2}$ \\ ${ }^{1}$ Fisheries Faculty, Ege University, TR-35100, Bornova, Izmir, Turkey. E-mail: hakan.kaykac@ege.edu.tr \\ ${ }^{2}$ Mersin University, Fisheries Faculty, Yenişehir Campus, TR-33169, Mersin, Turkey.
}

\begin{abstract}
SUMMARY: We investigated the differences between size selectivity of a commercial codend (40 mm diamond mesh - 40D), a larger mesh codend (48 mm diamond mesh - 48D), and a square mesh codend (40 mm square mesh - 40S) for Parapenaeus longirostris in international waters of the Aegean Sea. Selectivity data were collected by using a covered codend method and analysed taking between-haul variation into account. The results indicate significant increases in $\mathrm{L}_{50}$ values in relation to an increase in mesh size and when the square mesh is used in the commercial trawl codend. The results demonstrate that the commercially used codend (40D) is not selective enough for P. longirostris in terms of length at first maturity. Changing from a $40 \mathrm{D}$ to a $48 \mathrm{D}$ codend significantly improves selection, with an increase of about $15 \%$ in the $\mathrm{L}_{50}$ values (carapace length $14.5 \mathrm{~mm}$ for $40 \mathrm{D}$ and $16.6 \mathrm{~mm}$ for $48 \mathrm{D}$ ). Similarly, $40 \mathrm{~mm}$ square mesh, which has recently been legislated for EU Mediterranean waters, showed a 12.4\% higher mean $\mathrm{L}_{50}$ value $(16.3 \mathrm{~mm})$ than $40 \mathrm{~mm}$ diamond mesh for this species. However, despite these improvements, the $48 \mathrm{D}$ and $40 \mathrm{~S}$ codends still need further improvements to obtain higher selectivity closer to the length at first maturity (20 $\mathrm{mm}$ carapace length).
\end{abstract}

Keywords: Parapenaeus longirostris, mesh size, mesh shape, diamond mesh, square mesh.

RESUMEN: SELECTIVIDAD PARA MALLA MÁS GRANDE Y MALLA CUADRADA DE LOS COPOS COMERCIALES EN LA PESCA DE LA Gamba blanca Parapenaeus longirostris (LuCas, I846) EN El MAR EgeO. - Se estudian las diferencias entre la selectividad de los copos comerciales ( $40 \mathrm{~mm}$ de malla de diamante - 40D); copos de malla más grande (48 $\mathrm{mm}$ de malla de diamante -48D), y copos de malla cuadrada (40 mm - 40S), en la pesquería de Parapenaeus longirostris en aguas internacionales del mar Egeo. Para su estudio se utilizó el método del sobrecopo, y para su análisis, se tuvo en cuenta la variación intra-lances. Los resultados indican un incremento de los valores de $\mathrm{L}_{50}$ cuando se incrementa el tamaño de malla, y también con el uso de la malla cuadrada. Los resultados demuestran que el copo comercial actual (40D), no es suficientemente selectivo para $P$. longirostris en relación a la talla de primera madurez. El cambio, la malla de 48D, produce una mejora significativa en la selectividad cercana al $15 \%$ de incremento en los valores de la $\mathrm{L}_{50}$ (longitud del caparazón de $14.5 \mathrm{~mm}$ para 40D y $16.6 \mathrm{~mm}$ para 48D). Igualmente, la malla 40S, la cual ha sido legislada recientemente por la UE en aguas del Mediterráneo, muestra un incremento de la selectividad aproximadamente de un $12 \%$ en los valores de la $\mathrm{L}_{50}(16.3 \mathrm{~mm})$ respecto a la de $40 \mathrm{D}$. No obstante, a pesar de estas mejoras, los copos de 48D y 40S, todavía deberían ser ampliados para obtener selectividades más elevadas y acercarse a la talla de primera madurez (20 mm de caparazón).

Palabras clave: Parapenaeus longirostris, tamaño de malla, forma del malla, rombo, malla cuadrada.

\section{INTRODUCTION}

The deep water rose shrimp Parapenaeus longirostris (Crustacea, Decapoda, Penaeidae) is one of the prime target species in the Mediterranean demersal trawl fisheries due to its high economic value. The bathymetric range of this species in the Mediterranean is 20 to $700 \mathrm{~m}$ (Tom et al., 1988), and 
it generally lives on muddy or sandy-muddy bottoms on the upper slope at depths between 100 and 400 $\mathrm{m}$ (Holthuis, 1980). Differences in the size structure and sex ratio of $P$. longirostris have been related to depth (Relini et al., 1999; Rinelli et al., 2005; Abelló et al., 2002); larger specimens are more abundant in deeper areas, where males are also predominate. Although mature females are found in all seasons, reproduction starts in spring and the maximum percentage of mature females is in autumn and early winter (Relini et al., 1999). Individuals reach sexual maturity at 8 to 10 months at varying sizes, depending on the area (20 to $28 \mathrm{~mm}$ cephalothorax length in females), and have an average fecundity of 90000 eggs (Sobrino et.al., 2005).

$P$. longirostris is commercially caught by bottom trawls in the Aegean Sea. There is a 5-month seasonal closure for trawling in Turkish coastal waters (within 6 miles of the coast in the Aegean Sea) between April 15 and September 15 (Anonymous, 2008). For this reason, international waters of the Aegean Sea have become a popular fishing ground for many trawlers coming from the Black Sea and Mediterranean during the closed season (Tokaç et al., 2009).

Diamond-shaped mesh in trawl nets has a tendency to close during a tow due to certain internal and external effects (Robertson and Stewart, 1988; Reeves et al., 1992), which may cause an increase in by-catch. Recent studies have shown that selectivity of the trawl codends is rather poor for many commercially important species in Turkey (Tokaç et al., 1998, 2004; Tosunoğlu et al., 2007; Özbilgin et al., 2005), and other Mediterranean areas (e.g., Petrakis and Stergiou, 1997; Stergiou et al., 1997; Bahamon et al., 2006). Therefore, many researchers have suggested increasing the mesh size and/or changing the mesh shape in the codend. Many studies outside the Aegean Sea have shown that an increase in mesh size and a change of mesh shape in the trawl codends reduce the number of juvenile $P$. longirostris caught (Sobrino et al., 2000; Guijarro and Massutí, 2006; Rinelli et al., 2005; Ragonese and Bianchini, 2006). In addition, the General Fisheries Commission for the Mediterranean (GFCM) has encouraged studies aimed at improving selectivity and reducing the discards of this fleet (GFCM 2007). The Council Regulation (EC No. 1967/2006) of the European Commission concerned with management measures for sustainable exploitation of fishery resources in the Mediterranean Sea also requires EU countries that use towed nets, i.e. demersal trawls, to replace 40 $\mathrm{mm}$ diamond mesh with square mesh at the codend or, if the ship owner makes a justified request, with $50 \mathrm{~mm}$ diamond mesh. This same regulation establishes a Minimum Landing Size (MLS) of $20 \mathrm{~mm}$ carapace length (CL) for this species. Although there is no MLS for $P$. longirostris in Turkish Fisheries Regulations (Anonymous, 2008), Deval et al. (2006) and Tosunoğ lu et al. (2007) reported a length at first maturity (LFM) of $21 \mathrm{~mm}$ in Turkish waters.

The main objective of this study was to investigate the differences between size selectivity of a commercial $40 \mathrm{~mm}$ diamond shaped mesh codend, a larger mesh codend of $48 \mathrm{~mm}$ diamond shaped, and a $40 \mathrm{~mm}$ square mesh codend for $P$. longirostris in the international waters of the Aegean Sea.

\section{MATERIALS AND METHODS}

Selectivity experiments were conducted between August 1 and 15, 2005 on board the commercial trawler "Niyazi Reis" (294 KW, LOA 26.2 m) in the international waters of the Aegean Sea (Fig. 1). The trawl was a typical commercial bottom trawl used by the demersal fishery at this fishing ground. Technical information on this gear (conventional bottom trawl with 900 meshes around the circumference of the mouth) is described in detail by Tokaç et al. (2005).

A total of 22 valid hauls were carried out at depths ranging from 146 to $264 \mathrm{~m}$ during daylight hours, and a towing duration of between 165 and 405 minutes. The towing speed ranged between 2.2 and 2.3 knots.

The selectivity of three codends made of knotted polyethylene (PE) material was tested. The first codend was the commercially used $40 \mathrm{~mm}$ nominal mesh size diamond mesh codend (40D) with 300 meshes on its circumference (three seems of 100 mesh panels). A second codend was made of $48 \mathrm{~mm}$ diamond mesh (48D) netting with 275 meshes on its circumference. The stretched width of these two diamond mesh codends was kept constant, since this has proved to be a variable that can significantly affect selectivity (Robertson and Ferro, 1988; Reeves et al., 1992). Finally, the third codend was made of $40 \mathrm{~mm}$ square mesh (40S) netting with 150 meshes on its circumference. All the codends had stretched lengths of approximately $5.5 \mathrm{~m}$. They were attached to the end of the funnel, which was 300 meshes around the mouth, and made of $40 \mathrm{~mm}$ mesh size 


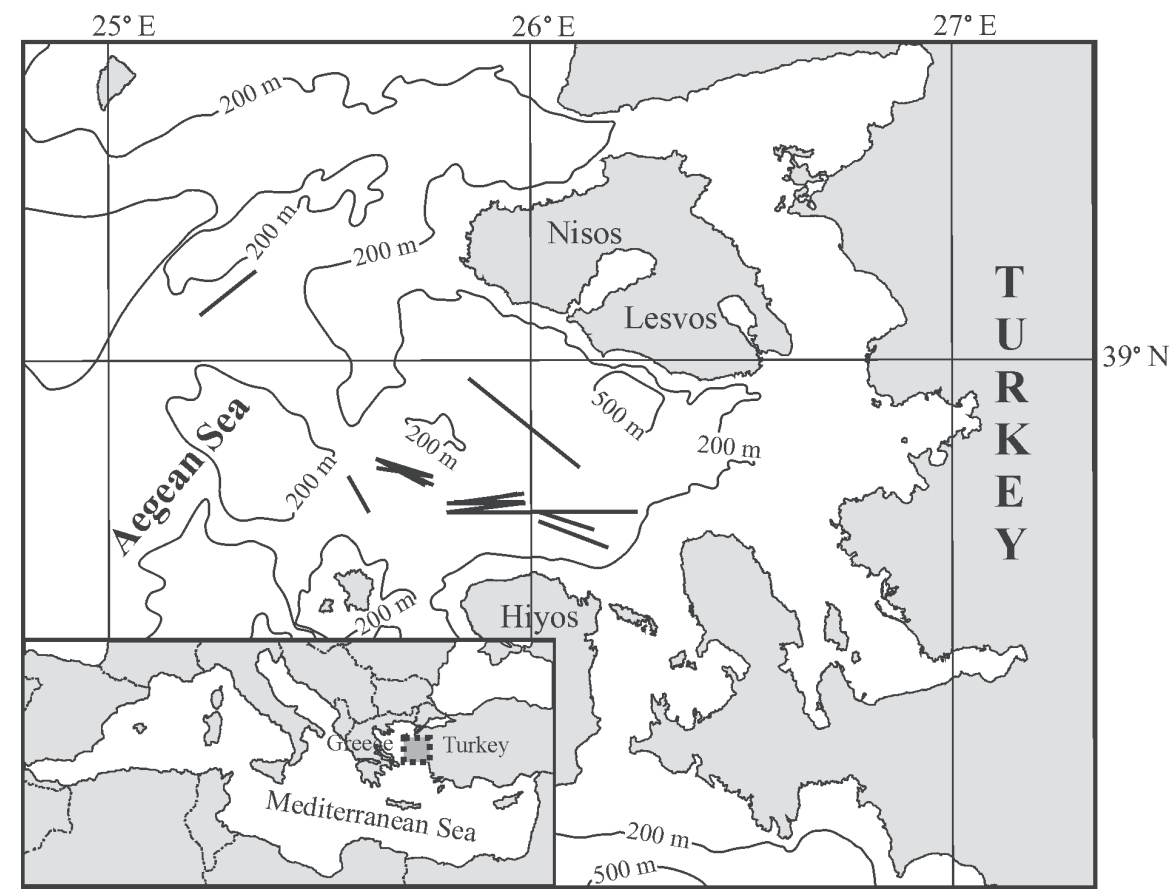

FIG. 1. - Map of the study area showing the fishing grounds of the Aegean Sea.

PE netting. The mean mesh size of each codend was measured by using a caliper rule with a $4 \mathrm{~kg}$ weight tied vertically to the stationary jaw of the rule.

A $10.2 \mathrm{~m}$ long, and $24 \mathrm{~mm}$ mesh size knotless PA (polyamide) netting cover was used to collect the individuals that escaped. The cover was supported by two hoops (PVC $\varnothing 1.9 \mathrm{~m}$ ) to avoid the masking effect and to provide water flow between the codend and the cover. These hoops were mounted on the cover at distances of 2 and 5 meters from the attachment point at the end of the funnel.

After each haul, the catch was taken on board and sorted by species. Then, full or sub-samples of the target species from the codend and cover were taken and weighted separately. All specimens were then sorted by sex. If there were more than 150 individuals for each sex, carapace lengths (CL) of a minimum of 150 specimens from the codend and cover were measured to the nearest $\mathrm{mm}$ (between the eye socket and the posterior margin of the carapace) by means of caliper rules. If the number of individuals was less than 150 , they were all measured.

Logistic selection curves for separate and combined sexes in each haul were obtained by fitting the logit function:

$$
r(l)=\exp \left(v_{1}+v_{2} l\right) / 1+\exp \left(v_{1}+v_{2} l\right)
$$

where $r(l)$ is the retained proportion of length class $l$, given that it entered the codend (Wileman et al., 1996), and $v=\left(v_{1}, v_{2}\right)^{\mathrm{T}}$ is the vector of the selectivity parameters. The values of $\mathrm{L}_{50}, \mathrm{~L}_{25}$ and $\mathrm{L}_{75}$ were estimated from the expressions:

$$
\begin{gathered}
L_{50}=\frac{-v_{1}}{v_{2}} \\
L_{25}=\frac{\left(-\ln (3)-v_{1}\right)}{v_{2}} \\
L_{75}=\frac{\left(\ln (3)-v_{1}\right)}{v_{2}}
\end{gathered}
$$

Selection Range (SR, difference between the $75 \%$ and $25 \%$ retention lengths) and Selection Factor (SF) were estimated with the equations:

$$
\begin{gathered}
S R=L_{75}-L_{25} \\
S F=\frac{L_{50}}{\text { meshsize }}
\end{gathered}
$$

These parameters were calculated with CC 2000 software (ConStat, 1995). Mean selectivity curves for separate and combined sexes in each haul were estimated taking into account the between haul variation of the selectivity parameters $v_{1}$ and $v_{2}$ according to Fryer (1991). ECModeller software (ConStat, 1995) was used for this analysis. The between haul variation model (Fryer, 1991) was also used for modelling the 
selectivity data. This analysis was initially carried out to detect the affect of the sex on the selection parameters. As the results showed that sex did not significantly affect them ( $p>0.05)$, the rest of the modelling was carried out with combined sex data from each haul. With these data we tested the effect of mesh size, mesh configuration, catch size and haul duration on selection parameters. Except for mesh configuration, which was adjusted as two level factors, all the other variables were adjusted as continuous. The model that best fitted the data was chosen according to the lowest value of Akaike's Information Criterion-AIC (Fryer and Shepherd, 1996).

\section{RESULTS}

The mean values of 60 mesh measurements of each codend were: $42.2 \mathrm{~mm}$ (SE. 0.20) for the 40D codend, $48.6 \mathrm{~mm}$ (SE. 0.15) for the 48D codend, and $42.9 \mathrm{~mm}$
(SE. 0.21) for the 40 S codend. All of the 22 valid hauls were used in the individual haul analysis: 10 hauls for 40D, 8 hauls for 48D and 4 hauls for 40 S. For all the codends, total catch, $5182.5 \mathrm{~kg}$, was composed of more than 50 species of fish, cephalopods and crustaceans. $P$. longirostris was the dominant species constituting about $25 \%$ of the total catch by weight. For this species, quantity of catch per hour in each codend varied between 15 and $17 \mathrm{~kg}$. In total, 100836 females and 104129 males were estimated to enter the codends, and a female male ratio of 1:1.03 was calculated. In general, female individuals in the catch composition were slightly larger than males (Table 1).

The CL of the specimens caught in the codends ranged from 7 to $37 \mathrm{~mm}$ for combined sexes. Length frequency distributions were multi-modal, with major peaks at about 22 and $26 \mathrm{~mm}$ CL (corresponding to males and females respectively) and minor peaks at about 15 and $16 \mathrm{~mm}$ (corresponding to males and females respectively) (Fig. 2).

TABLE 1. - Results of selectivity parameter estimates, and number of specimens in codend and cover of 40D (40 mm diamond mesh), 48D (48 $\mathrm{mm}$ diamond mesh), and 40S (40 mm square mesh) for combined ( $++\hat{\phi})$, male only $(\hat{0})$, and female only ( $q$ ) specimens. Numbers in brackets are standard errors. $\mathrm{L}_{50}$, fifty percent retention length; $v_{1}$ and $v_{2}$, maximum likelihood estimators of the selectivity parameters; $R_{l 1}, R_{12}$, and $R_{22}$, variance matrix measuring the within-haul variation; d.f., degrees of freedom; $\mathrm{n}$, the numbers of individuals in the codend and cover.

\begin{tabular}{|c|c|c|c|c|c|c|c|c|c|c|c|c|}
\hline Haul & $\mathrm{L}_{50}$ & $(\mathrm{SE})$ & SR & (SE) & $v_{1}$ & $v_{2}$ & $R_{11}$ & $R_{12}$ & $R_{22}$ & d.f. & $\mathrm{n}($ codend $)$ & $\mathrm{n}$ (cover) \\
\hline \multicolumn{13}{|l|}{ 40D } \\
\hline 2 & 14.37 & $(0.4)$ & 5.62 & $(0.4)$ & -5.615 & 0.391 & 0.2273 & -0.0117 & 0.0006 & 24 & 16037 & 1505 \\
\hline 3 & 14.84 & $(0.8)$ & 6.47 & $(0.8)$ & -5.045 & 0.340 & 0.7158 & -0.0335 & 0.0016 & 21 & 8822 & 760 \\
\hline 16 & 14.29 & $(0.3)$ & 5.97 & $(0.3)$ & -5.255 & 0.368 & 0.1581 & -0.0083 & 0.0005 & 25 & 9760 & 1107 \\
\hline 17 & 14.80 & $(0.2)$ & 4.77 & $(0.2)$ & -6.810 & 0.460 & 0.1762 & -0.0098 & 0.0006 & 28 & 7735 & 1076 \\
\hline 18 & 14.64 & $(0.4)$ & 5.81 & $(0.4)$ & -5.534 & 0.378 & 0.3007 & -0.0155 & 0.0008 & 22 & 4098 & 422 \\
\hline 19 & 13.38 & $(0.4)$ & 5.14 & $(0.4)$ & -5.721 & 0.428 & 0.3382 & -0.0188 & 0.0011 & 26 & 5842 & 342 \\
\hline 20 & 14.01 & $(0.5)$ & 5.61 & $(0.5)$ & -5.486 & 0.391 & 0.3377 & -0.0178 & 0.0010 & 23 & 2827 & 223 \\
\hline 32 & 14.89 & $(0.6)$ & 5.24 & $(0.5)$ & -6.238 & 0.419 & 0.6591 & -0.0330 & 0.0017 & 23 & 7903 & 729 \\
\hline 33 & 14.38 & $(0.5)$ & 5.62 & $(0.5)$ & -5.628 & 0.391 & 0.4271 & -0.0215 & 0.0011 & 24 & 6212 & 488 \\
\hline 34 & 14.74 & $(0.4)$ & 5.86 & $(0.3)$ & -5.524 & 0.375 & 0.1890 & -0.0094 & 0.0005 & 23 & 5424 & 546 \\
\hline Mean $q+\hat{\sigma}$ & 14.49 & $(0.1)$ & 5.55 & $(0.1)$ & -5.666 & 0.393 & 0.0394 & -0.0023 & 0.0001 & 15 & 74660 & 7198 \\
\hline Mean $q$ only & 14.70 & $(0.1)$ & 5.55 & $(0.1)$ & -5.746 & 0.390 & 0.0536 & -0.0032 & 0.0002 & 15 & 32928 & 3891 \\
\hline Mean $\delta$ only & 14.36 & $(0.1)$ & 5.53 & $(0.1)$ & -5.424 & 0.383 & 0.1465 & -0.0065 & 0.0003 & 15 & 41732 & 3307 \\
\hline \multicolumn{13}{|l|}{ 48D } \\
\hline 22 & 17.22 & $(0.5)$ & 7.81 & $(0.7)$ & -4.842 & 0.281 & 0.2842 & -0.0132 & 0.0006 & 22 & 13150 & 3728 \\
\hline 23 & 17.19 & $(0.4)$ & 7.71 & $(0.6)$ & -4.901 & 0.285 & 0.1967 & -0.0097 & 0.0005 & 25 & 9240 & 3732 \\
\hline 24 & 18.38 & $(0.3)$ & 5.77 & $(0.4)$ & -6.995 & 0.381 & 0.3688 & -0.0172 & 0.0008 & 22 & 7369 & 2392 \\
\hline 26 & 17.23 & $(0.2)$ & 3.89 & $(0.2)$ & -9.745 & 0.565 & 0.5578 & -0.0289 & 0.0015 & 22 & 12002 & 2056 \\
\hline 28 & 17.51 & $(0.3)$ & 5.30 & $(0.4)$ & -7.253 & 0.414 & 0.3335 & -0.0171 & 0.0009 & 23 & 3196 & 1316 \\
\hline 29 & 14.88 & $(0.3)$ & 6.88 & $(0.4)$ & -4.749 & 0.319 & 0.1307 & -0.0068 & 0.0004 & 24 & 11028 & 2328 \\
\hline 30 & 15.02 & $(0.5)$ & 7.90 & $(0.7)$ & -4.177 & 0.278 & 0.2006 & -0.0102 & 0.0005 & 24 & 10070 & 2608 \\
\hline 31 & 15.10 & $(0.5)$ & 7.33 & $(0.7)$ & -4.525 & 0.300 & 0.3183 & -0.0162 & 0.0009 & 22 & 4285 & 928 \\
\hline Mean ++0 & 16.61 & $(0.2)$ & 6.48 & $(0.2)$ & -5.816 & 0.348 & 0.4276 & -0.0215 & 0.0011 & 11 & 70340 & 19088 \\
\hline Mean $q$ only & 17.09 & $(0.2)$ & 6.38 & $(0.2)$ & -5.991 & 0.349 & 0.4374 & -0.0212 & 0.0011 & 11 & 36637 & 10004 \\
\hline Mean $\widehat{o}$ only & 16.36 & $(0.2)$ & 6.07 & $(0.2)$ & -5.277 & 0.331 & 0.1093 & -0.0051 & 0.0003 & 11 & 33703 & 9084 \\
\hline \multicolumn{13}{|l|}{$40 \mathrm{~S}$} \\
\hline 35 & 16.53 & $(0.2)$ & 3.77 & $(0.2)$ & -9.625 & 0.582 & 0.2700 & -0.0142 & 0.0008 & 23 & 6896 & 972 \\
\hline 36 & 17.11 & $(0.2)$ & 3.73 & $(0.3)$ & -10.086 & 0.589 & 0.6313 & -0.0336 & 0.0018 & 24 & 3803 & 956 \\
\hline 37 & 15.07 & $(0.3)$ & 5.34 & $(0.4)$ & -6.200 & 0.411 & 0.2720 & -0.0147 & 0.0008 & 24 & 7292 & 1232 \\
\hline 38 & 16.41 & $(0.2)$ & 4.55 & $(0.3)$ & -7.932 & 0.483 & 0.3494 & -0.0192 & 0.0011 & 22 & 9760 & 2768 \\
\hline Mean $q+\hat{0}$ & 16.29 & $(0.2)$ & 4.28 & $(0.2)$ & -8.254 & 0.519 & 0.8487 & -0.0400 & 0.0019 & 3 & 27751 & 5928 \\
\hline Mean $q$ only & 16.77 & $(0.3)$ & 4.15 & $(0.3)$ & -9.037 & 0.534 & 1.6225 & -0.0776 & 0.0038 & 3 & 13900 & 3476 \\
\hline Mean $\delta$ only & 15.74 & $(0.1)$ & 4.63 & $(0.1)$ & -7.251 & 0.465 & 0.3552 & -0.0178 & 0.0009 & 3 & 13851 & 2452 \\
\hline
\end{tabular}



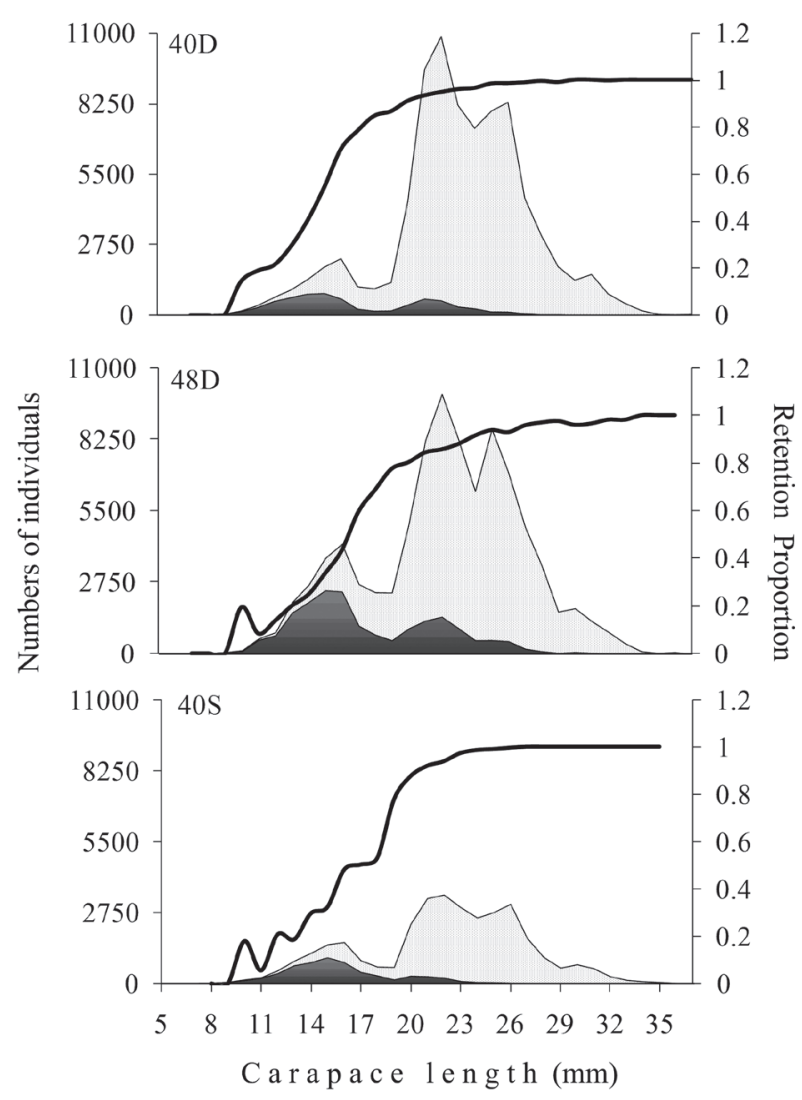

FIG. 2. - Numbers of size distributions of specimens that entered (grey area) and escaped (black area) for 40D (40 mm diamond mesh), 48D (48 mm diamond mesh), and 40S (40 mm square mesh) codends. Dark black lines show the retention proportions in these codends.
Proportions of $P$. longirostris retained in the codends were 0.96 (SE. 0.00), 0.88 (SE. 0.02), and 0.94 (SE. 0.01) in terms of weight, and 0.91 (SE. 0.01 ), 0.78 (SE. 0.02), and 0.83 (SE. 0.02) in terms of numbers for $40 \mathrm{D}, 48 \mathrm{D}$, and $40 \mathrm{~S}$ respectively. It stands out that, in terms of weight, the commercially used 40D has 0.08 and 0.03 higher retention ratios than $48 \mathrm{D}$ and $40 \mathrm{~S}$ respectively.

The results of the selectivity parameter estimates, and number of specimens in the codend and cover for combined sex, only male, and only female $P$. longirostris are presented in Table 1. In this study, none of the $\mathrm{L}_{50}$ or $\mathrm{SR}$ values of the three codends were significantly different for males or females. For the combined sexes, mean $\mathrm{L}_{50}$ values of $14.49,16.61$, and $16.29 \mathrm{~mm}$ and mean SR values of $5.55,6.48$, and $4.28 \mathrm{~mm}$ were estimated for $40 \mathrm{D}, 48 \mathrm{D}$, and $40 \mathrm{~S}$ respectively (Fig. 3).

The model which best described the data was:

$$
E\left(\begin{array}{c}
L_{50} \\
S R
\end{array}\right)=\left(\begin{array}{l}
\alpha_{1} t_{i}+\alpha_{3} m_{i} \\
\alpha_{2} t_{i}+\alpha_{4} m_{i}
\end{array}\right)
$$

where $\left(m_{i}\right)$ mesh size, $\left(t_{i}\right)$ mesh configuration and $\alpha$ is the vector that determines the direction and magnitude of the influence of the explanatory variables on the selectivity parameters ( $\mathrm{L}_{50}$ and $\mathrm{SR}$ ).
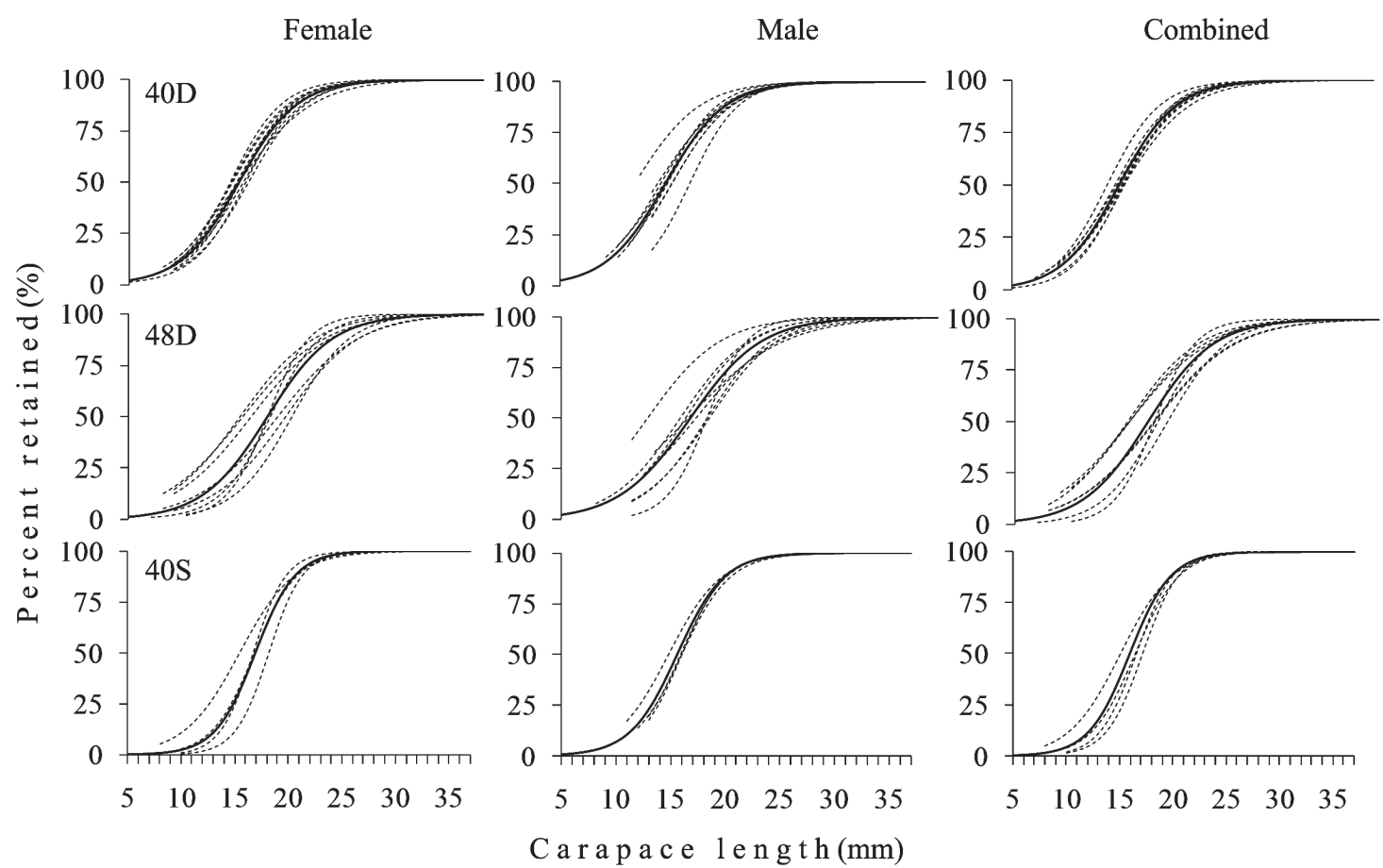

FIG. 3. - Selection curves of 40D (40 mm diamond mesh), 48D (48 mm diamond mesh), and 40S (40 mm square mesh) codends for Parapenaeus longirostris for combined sexes, only males, and only females. Dotted lines are individual curves and thicker black lines are mean selection curves. 
TABLE 2. - Alpha parameter estimates (in bold), standard deviation (S.D.), $t$-Value, degrees of freedom and $p$-Value for $P$. longirostris. $m_{i}$, mesh size, $t_{i}$, mesh configuration and $\alpha$ is the vector that determines the direction and magnitude of the influence of the explanatory variables on the selectivity parameters $\left(\mathrm{L}_{50}\right.$ and $\left.\mathrm{SR}\right)$.

\begin{tabular}{llccccc}
\hline & & Estimate & S.D. & $t$-Value & d.f. & $p$-Value \\
\hline$\alpha_{1}$ & $\left(\mathrm{~L}_{50}, t_{i}\right)$ & 2.167 & 0.515 & 4.205 & 37 & 0.000 \\
$\alpha_{2}$ & $\left(\mathrm{SR}, t_{i}\right)$ & -1.148 & 0.516 & -2.223 & 37 & 0.032 \\
$\alpha_{3}$ & $\left(\mathrm{~L}_{50}, m_{i}\right)$ & 0.353 & 0.005 & 66.139 & 37 & 0.000 \\
$\alpha_{4}$ & $\left(\mathrm{SR}, m_{i}\right)$ & 0.137 & 0.005 & 25.063 & 37 & 0.000 \\
\hline
\end{tabular}

The results of the alpha parameter estimates are given in Table 2 along with their standard deviations and $t$-values. $\mathrm{L}_{50}$ and $\mathrm{SR}$ values are significantly affected by the mesh configuration and mesh size $(\mathrm{p}<0.05)$, while catch size and haul duration do not have a significant effect on these values $(p>0.05)$. Increasing mesh size from 40 to $48 \mathrm{~mm}$ significantly increases both the $\mathrm{L}_{50}$ and $\mathrm{SR}$ values $(\mathrm{p}=0.000)$. Similarly, changing from the diamond to square mesh configuration increases the $\mathrm{L}_{50}(\mathrm{p}=0.000)$, and reduces the $S R$ value $(\mathrm{p}=0.032)$.

\section{DISCUSSION}

The results of this work indicate that the commercially used $40 \mathrm{~mm}$ mesh size PE codend (40 D) is not selective enough to release immature specimens of rose shrimp in the Aegean Sea. Studies that tested similar mesh size diamond codends in the Mediterranean and adjacent waters generally report similar conclusions (Table 3). However, due to the differences in gear constructions, twine thickness, materials used, and fishing grounds, the results of most of these studies are not strictly comparable to those found in the present work (Tokaç et al., 2009). For example, the twine diameter of the codends tested in the present study $(1.3 \mathrm{~mm})$ is much thinner than that used by Greek, Italian, and Spanish trawlers, and Sala et al. (2008) demonstrate that this characteristic of codend netting significantly influences selectivity. Nevertheless, Tokaç et al. (2009) found a slightly lower $\mathrm{L}_{50}$ value $(12.7 \mathrm{~mm})$ using the same codend. This difference might have been caused by the variation in fishing depth and population size structure.

Using a larger mesh size in the codend has been reported to result in an increase in $\mathrm{L}_{50}$ values for rose shrimp (see Ragonese and Bianchini, (2006) for review, and Table 3). A shift from 40D to 48D codends in the present study significantly improved selectivity of rose shrimp with an increase of about $15 \%$ in the $\mathrm{L}_{50}$ values, while the Selection Factors (SF) remained the same $(0.34)$ for both codends. However, the SF of these codends is about $10 \%$ lower than the average SF (0.38) of the recently published selectivity studies, which tested diamond codends of between 36 and $55 \mathrm{~mm}$ mesh size (Table 3). A

TABLE 3. - Result of the previous studies in the Mediterranean and adjacent waters. NMS, Nominal mesh size; MMS, measured mesh size; $\mathrm{CL}_{50 \%}$, fifty percent retention length (CL-Carapace length); SR, selection range; SF, selection factor.

\begin{tabular}{|c|c|c|c|c|c|c|}
\hline Reference & $\begin{array}{l}\text { NMS } \\
(\mathrm{mm})\end{array}$ & $\begin{array}{l}\mathrm{MMS} \\
(\mathrm{mm})\end{array}$ & $\begin{array}{l}\mathrm{CL}_{50 \%} \\
(\mathrm{~mm})\end{array}$ & $\begin{array}{c}\mathrm{SR} \\
(\mathrm{mm})\end{array}$ & $\mathrm{SF}$ & Study Area \\
\hline \multicolumn{7}{|l|}{ DIAMOND } \\
\hline \multirow[t]{8}{*}{ Sobrino et al. (2000) } & - & 35.9 & 14.3 & 3.1 & 0.40 & Spanish \\
\hline & - & 42.8 & 20.9 & 6.7 & 0.49 & South Atlantic \\
\hline & - & 46.0 & 19.2 & 6.6 & 0.42 & \\
\hline & - & 52.7 & 19.2 & 8.4 & 0.36 & \\
\hline & 40 & - & 12.8 & 5.4 & 0.32 & \\
\hline & 40 & - & 15.8 & 3.0 & 0.39 & \\
\hline & 40 & - & 15.2 & 3.2 & 0.38 & \\
\hline & 40 & - & 14.7 & 3.4 & 0.37 & \\
\hline Campos et al. (2002) & 55 & 55.2 & 21.8 & 5.7 & 0.39 & Portuguese South Cost \\
\hline Rinelli et al. (2005) & 36 & - & 14.1 & 4.0 & 0.39 & Southern Tyrrhenian \\
\hline Guijarro and Massutí (2006) & 40 & - & 16.6 & 3.8 & 0.42 & Western Mediterranean \\
\hline Tosunoğlu et al. (2007) & 46 & 49.4 & 19.7 & 6.1 & 0.40 & Eastern Aegean \\
\hline Sala et al. (2008) & 40 & 39.0 & 12.0 & 2.4 & 0.31 & Northern Adriatic \\
\hline Tokaç et al. (2009) & 40 & 42.0 & 12.7 & 6.2 & 0.30 & Eastern Aegean \\
\hline \multirow[t]{2}{*}{ Present Paper } & 40 & 42.2 & 14.5 & 5.6 & 0.34 & Eastern Aegean \\
\hline & 48 & 48.6 & 16.6 & 6.5 & 0.34 & Eastern Aegean \\
\hline \multicolumn{7}{|l|}{ SQUARE } \\
\hline Sala et al. (2008) & 40 & 39.0 & 14.9 & 2.6 & 0.38 & Northern Adriatic \\
\hline Aydin et al. (2009) & 40 & 42.4 & 16.7 & 6.5 & 0.39 & Eastern Aegean \\
\hline Guijarro and Massutí (2006) & 40 & - & 20.2 & 2.3 & 0.51 & Western Mediterranean \\
\hline Campos et al. (2002) & 55 & 55.2 & 27.1 & 9.3 & 0.49 & Portuguese South Cost \\
\hline Present Paper & 40 & 42.9 & 16.3 & 4.3 & 0.38 & Eastern Aegean \\
\hline
\end{tabular}


combination of the variations in gear constructions, twine thickness, materials used, and fishing grounds might have caused this difference.

Changing the mesh configuration from diamondto square-shaped in the codend significantly improves the selectivity. The results of the square mesh codend (40S) in the present study show a mean $\mathrm{L}_{50}$ value that is about $12.4 \%$ higher than that of the commercial codend (40D) for this species. By changing the mesh configuration, similar improvements in codend selection were also reported by Campos et al. (2002) for $55 \mathrm{~mm}$ mesh size and by Guijarro and Massutí (2006) and Sala et al. (2008) for $40 \mathrm{~mm}$ mesh size (Table 3).

Both alternative codends tested in the present study have shown to improve selectivity of rose shrimp. However, neither of these modifications is sufficient for achieving sustainable exploitation of this shrimp stock. There is no MLS defined for this species in the Turkish Fisheries Regulations (Anonymous, 2008); however, its length at first maturity is known to be $20 \mathrm{~mm}$ (Meriem et al., 2001), and in the EU countries around the Mediterranean Sea this species has an MLS of $20 \mathrm{~mm}$ CL (EC Reg. 1967/2006). Therefore, using any of the three codends tested in the present study will tend to reduce the spawning potential of the stock. Sala et al. (2008) also stated this for 40D and 40S codends. Therefore, as tested by Campos et al. (2002), enforcement of a larger mesh size, which would assure that the mesh opens to an established size during trawling, is essential for immature specimens to be released. Nevertheless, it has to be taken into account that demersal trawling in the Mediterranean has a multi-species character, with more than 50 species caught in the gear (Petrakis and Stergiou, 1997). Thus, any effort to release immature shrimps in this mixed fishery is likely to cause loss of marketable sizes of many other species (Tokaç et al., 2009). The authors of the present study therefore recommend future research to focus not only on size but also species selectivity.

\section{ACKNOWLEDGEMENTS}

The authors would like to thank the captain and crew of the commercial trawler "Niyazi Reis". Thanks are also due to Dr. Z. Tosunoğlu, Dr. C. Aydın, Dr. G. Gökçe, S. Leblebici, I. Aydın, and O. Soykan for participating in the sea trials. This study was financed by the Commission of the European Union (NECESSITY/501605).

\section{REFERENCES}

Abelló, P., A. Abella, A. Adamidou, S. Jukic-Peladic, P. Maiorano and M.T. Spedicato. - 2002. Geographical patterns in abundance and population structure of Nephrops norvegicus and Parapenaeus longirostris (Crustacea: Decapoda) along the European Mediterranean coasts. Sci. Mar., 66(2): 125-141.

Anonymous. - 2008. 2/1 numaralı ticari su ürünleri avcılığını düzenleyen tebliğ (Tebliğ no: 2008/48). Tarım ve Köyişleri Bakanlığı, Koruma ve Kontrol Genel Müdürlüğü, Ankara.

Aydın, C. and Z. Tosunoğlu. - 2009. Selectivity of square and hexagonal mesh codends for the deep water rose shrimp, Parapenaeus longirostris (Lucas, 1846) (Decapoda, Penaeidae) in the Aegean Sea. Crustac. Int. J. Crustac. Res.

Bahamon, N., F. Sardà and P. Suuronen. - 2006. Improvement of trawl selectivity in the NW Mediterranean demersal fishery by using a $40 \mathrm{~mm}$ square mesh codend. Fish. Res., 81: 15-25.

Campos, A., P. Fonseca and K. Erzini. - 2002. Size selectivity of diamond and square mesh cod ends for rose shrimp (Parapenaeus longirostris) and Norway lobster (Nephrops norvegicus) off the Portuguese south coast. Fish. Res., 58: 281-301.

ConStat. - 1995. CC selectivity. (Granspaettevej 10, DK-9800 Hjjlarring, Denmark).

Council Regulation. - 2006. (EC) No 1967/2006 of 21 December 2006, concerning management measures for the sustainable exploitation of fishery resources in the Mediterranean Sea, amending Regulation (EEC) No 2847/93 and repealing Regulation (EC) No 1626/94. Official J. Eur. Union L. 409.

Deval, M.C., T. Bök, C. Ateş and H. Özbilgin. - 2006. Selectivity of PE and PA material codends for rose shrimp (Parapenaeus longirostris) in Turkish twin rigged beam trawl fishery. Fish. Res., 81: 72-79.

Fryer, R.J. - 1991. A model of between-haul variation in selectivity. ICES J. Mar. Sci., 48: 281-290.

Fryer, R.J., Shepherd, J.G., 1996. Models of codend size selection. J.Northwest Atl. Fish. Sci. 19: 91-102

GFCM. - 2007. FAO Report of the tenth session of the Scientific Advisory Committee, Nicosia, Cyprus, 22-26 October 2007. Fish. Rep. 856: 1-157.

Guijarro, B. and E. Massutí. - 2006. Selectivity of diamond- and square-mesh codends in the deepwater crustacean trawl fishery off the Balearic Island (western Mediterranean). ICES J. Mar. Sci., 63: 52-67.

Holthuis, L.B. - 1980. FAO species catalogue, 1. Shrimps and prawns of the world. An annotated catalogue of species of interest to fisheries. FAO Fish. Synop., 125: 1-261.

Meriem, S.B., R. Fehri-Bedoui and H. Gharbi. - 2001. Size at maturity and ovigerous period of the pink shrimp Parapenaeus longirostris (Lucas, 1846) in Tunisia. Crustac. Int. J. Crustac. Res., 74: 39-48.

Özbilgin, H., Z. Tosunoğlu, C. Aydın, H. Kaykaç and A. Tokaç. -2005 . Selectivity of Standard, Narrow and Square Mesh Panel Trawl Codends for Hake (Merluccius merluccius) and Poor Cod (Trisopterus minutus capelanus). Turk. J. Vet. Anim. Sci., 29: 967-973.

Petrakis, G. and K.I. Stergiou. - 1997. Size selectivity of diamond and square mesh codends for four commercial Mediterranean fish species. ICES J. Mar. Sci., 54: 13-23.

Ragonese S. and M.L. Bianchini. - 2006. Trawl selectivity trials on the deep-water rose shrimp (Parapenaeus longirostris) in Sicilian waters. In: M. Thessalou-Legaki (ed.), Issues of Decapod Crustacean Biology. Hydrobiologia, 557: 113-119.

Reeves S.A., D.W. Armstrong, R.J. Fryer and K.A. Coull. - 1992. The effects of mesh size, cod-end extension length and cod-end diameter on the selectivity of Scottish trawls and seines. ICES J. Mar. Sci., 49: 279-288.

Relini, G., J. Bertrand and A. Zamboni. - 1999. Synthesis of the knowledge on bottom fishery resources in Central Mediterranean. Biol. Mar. Medit. 6(Suppl. 1): 1-868.

Rinelli, P., D. Giordano, F. Perdichizzi, S. Greco and S. Ragonese. -2005 . Trawl gear selectivity on the deep-water rose shrimp (Parapenaeus longirostris, Lucas, 1846) in the southern Tyrrhenian Sea (central Mediterranean). Cah. Biol. mar., 46: 1-7.

Robertson, J.H.B. and R.S.T Ferro. - 1988. Mesh selection within the cod-end of trawls. The effects of narrowing the cod-end and shortening the extension. Scot. Fish. Res. Report No 39: 11. 
Robertson, J.H.B. and P.A.M. Stewart. - 1988. A comparison of size selection of haddock and whiting by square and diamond mesh codends. J. Cons. Explor. Mer., 44: 148-161.

Sala, A., A. Luchetti, C. Piccinetti and M. Ferretti. - 2008. Size selection by diamond- and square-mesh codends in multi-species Mediterranean demersal trawl fisheries. Fish. Res., 93: 8-21.

Sobrino, I., G. Teresa and J. Baro. - 2000. Trawl gear selectivity and the effect of mesh size on the deep-water rose shrimp (Parapenaeus longirostris Lucas, 1846) fishery off the Gulf of Cádiz (SW Spain). Fish. Res., 44: 235-245.

Sobrino, I., C. Silva, M. Sbrana and K. Kapiris. - 2005. A review of the biology and fisheries of the deep water rose shrimp, Parapenaeus longirostris, in European Atlantic and Mediterranean waters (Decapoda, Dendrobranchiata, Penaeidae). Crustac. Int. J. Crustac. Res., 78: 1153-1184.

Stergiou, K.I., G. Petrakis and C.-Y. Politou. - 1997. Size selectivity of diamond and square mesh codends for Nephrops norvegicus in the Aegean Sea. Fish. Res., 29: 203-209.

Tokaç, A., A. Lök, Z. Tosunoğlu, C. Metin and R.S.T. Ferro. - 1998. Codend selectivities of a modified bottom trawl for three fish species in the Aegean Sea. Fish. Res., 39: 17-31.

Tokaç, A., H. Özbilgin and Z. Tosunoğlu. - 2004. Effect of PA and PE material on codend selectivity in Turkish bottom trawl. Fish. Res., 67: 317-327.
Tokac, A., Z. Tosunoğlu, G. Gökçe, H. Kaykac and H. Özbilgin. 2005. Technical drawing and specifications of 900 mesh traditional bottom trawl net in Turkish demersal fisheries. J. Fish. Aquat. Sci., 22: 439-442.

Tokaç, A., H. Özbilgin and H. Kaykaç. - 2009. Alternative codend designs to improve size selectivity for Norway lobster (Nephrops norvegicus) and Rose shrimp (Parapenaeus longirostris) in the Aegean Sea. Crustac. Int. J. Crustac. Res., 82: 689-702.

Tom, M., M. Gorem and M. Ovadia. - 1988. The benthic phases of life cycle of Parapenaeus longirostris (Crustacea, Decapoda, Penaeidae) along the Mediterranean coast of Israel. Hydrobiologia, 169: 339-352.

Tosunoğlu, Z., C. Aydın, O. Özaydın and S. Leblebici. - 2007. Trawl codend mesh selectivity of braided PE material for Parapenaeus longirostris (Lucas, 1846) (Decapoda, Penaeidae) Crustac. Int. J. Crustac. Res., 80: 1087-1094.

Wileman, D.A., R.S.T. Ferro, R. Fonteyne and R.B. Millar (eds.). - 1996. Manual of Methods of Measuring the Selectivity of Towed Fishing Gears. ICES Coop. Res. Rep. No., 215. (Copenhagen).

Scient. ed.: F. Sardà.

Received September 17, 2008. Accepted January 21, 2009.

Published online May 19, 2009. 